Article

\title{
Evaluating the Impact of Alternative Cropping Systems on Groundwater Consumption and Nitrate Leaching in the Piedmont Area of the North China Plain
}

\author{
Meiying Liu ${ }^{1,2,3}$, Leilei Min ${ }^{1,2, *}$, Yanjun Shen ${ }^{1,2}$ and $\operatorname{Lin} \mathrm{Wu}^{1,2,3}$ \\ 1 Hebei Key Laboratory of Water-Saving Agriculture, Key Laboratory of Agricultural Water Resources, \\ Center for Agricultural Resources Research, Institute of Genetics and Developmental Biology, \\ Chinese Academy of Sciences, Shijiazhuang 050021, China; myliu@sjziam.ac.cn (M.L.); \\ yjshen@sjziam.ac.cn (Y.S.); wulin@sjziam.zc.cn (L.W.) \\ 2 Innovative Academy of Seed Design, Chinese Academy of Sciences, Beijing 100101, China \\ 3 University of the Chinese Academy of Sciences, Beijing 100049, China \\ * Correspondence: 1lmin@sjziam.ac.cn; Tel.: +86-0311-85800019
}

Received: 21 September 2020; Accepted: 21 October 2020; Published: 23 October 2020

\begin{abstract}
The overexploitation of groundwater and the excessive application of nitrogen $(\mathrm{N})$ fertilizer under the intensive double cropping system are responsible for the groundwater level decline and potential contamination in the North China Plain (NCP). Alternative cropping systems have the potential to alleviate current groundwater and $\mathrm{N}$ problems in the region, while there are limited studies simultaneously focusing on the impact of a change of cropping systems on crop yields, groundwater consumption, and $\mathrm{N}$ leaching. In this study, Field observed experiments of double-cropping system (i.e., winter wheat-summer maize) and mono-cropping system (early sowing maize) were used to calibrate and validate the Root Zone Water Quality Model (RZWQM2). Then, the validated RZWQM2 model was used to evaluate the long-term crop growth and environmental impact under the local winter wheat-summer maize rotation system with practical irrigation (WW-SM_pi) and auto-irrigation (WW-SM_ai), and three alternative cropping systems (single early maize, SEM; winter wheat-summer maize and single early maize, WW-SM-SEM; winter wheat-summer maize and double single early maize, WW-SM-2SEM). The net consumption of groundwater and N leaching under WW-SM_pi were $226.9 \mathrm{~mm} \mathrm{yr}^{-1}$ and $79.7 \mathrm{~kg} \mathrm{ha}^{-1} \mathrm{yr}^{-1}$, respectively. Under the local rotation system, auto-irrigation could increase crop yields and $\mathrm{N}$ leaching. Compared with the WW-SM_ai, the alternative cropping systems, WW-SM-SEM, WW-SM-2SEM, and SEM, significantly decreased the net consumption of groundwater by $49.3 \%, 63.0 \%$, and $97.8 \%$, respectively $(147.5-292.9 \mathrm{~mm})$, and $\mathrm{N}$ leaching by $53.5 \%, 67.5 \%$, and $89.6 \%$, respectively $\left(50.0-83.7 \mathrm{~kg} \mathrm{ha}^{-1}\right)$. However, the yields of the three alternative cropping systems were reduced by less than $30 \%(12.2 \%, 20.1 \%$, and $29.7 \%$, respectively). The simulated results indicated that appropriately decreasing the planting frequency of winter wheat is an effective approach to reduce groundwater overexploitation and $\mathrm{N}$ contamination with a relatively limited reduction in grain yields. The results could provide a scientific basis for cropping system adjustment in guaranteeing sustainable regional water and grain policy.
\end{abstract}

Keywords: wheat; maize; nitrate polution; grain yield; evapotranspiration; groundwater overexploitation; RZWQM2 model

\section{Introduction}

The North China Plain (NCP) is a crucial area for grain production in China. The plain supplies approximately $20 \%$ of national grain production [1], playing a significant role in guaranteeing regional 
and national food security. The prevailing cropping system, the double rotation system of winter wheat and summer maize, meets the grain demand in this region, but gives rise to some adverse impacts, such as water table deline, rivers drying up, soil nitrate accumulation, and groundwater contamination [2,3]. Under the current rotation system, the annual evapotranspiration (ET) in the piedmont area of NCP ranges from about $700 \mathrm{~mm}$ to more than $800 \mathrm{~mm}[4,5]$, which is higher than the annual precipitation $(496 \mathrm{~mm}$ ) [6]. Therefore, precipitation cannot meet the crop water requirement. In addition, the gaps occur mainly in the winter wheat season, as the ET of winter wheat considerably exceeds the precipitation during its growth period $[5,7,8]$. In order to ensure the normal growth and development of the crop, irrigation is necessary to supplement the water deficit. During the past three decades, about $70 \%$ groundwater consumption was exploited for crop irrigation, resulting in a continuous decline in the groundwater level in the region $[6,9,10]$.

Generally, water and nitrogen $(\mathrm{N})$ are the two critical factors to ensure grain production [11]. To pursue high production, excessive $\mathrm{N}$ fertilizer $\left(400-600 \mathrm{~kg} \mathrm{~N} \mathrm{ha}^{-1}\right)$ has been applied to the current rotation system, which exceeds the crop demands of 200 to $300 \mathrm{~kg} \mathrm{~N} \mathrm{ha}^{-1}[4,12,13]$. Overall, the applied $\mathrm{N}$ fertilizer would be absorbed by the crops, stored in the root zone, and lost by ammonia volatilization, $\mathrm{N}$ leaching, $\mathrm{N}_{2} \mathrm{O}$ and $\mathrm{N}_{2}$ emissions. The soil in the NCP, with a semi-arid and semi-humid monsoon climate has relatively stable nitrification and mineralization capacity, which makes it easy to accumulate nitrate-nitrogen $\left(\mathrm{NO}_{3}{ }^{-}-\mathrm{N}\right)$ in the root zone $[14,15]$. The $\mathrm{NO}_{3}{ }^{-}-\mathrm{N}$ accumulated in the root zone would move downward continuously carried by percolated soil water, and eventually enter the groundwater. Therefore, the overuse of $\mathrm{N}$ fertilizer and flood irrigation has caused severe $\mathrm{N}$ leaching $(15-55 \% \mathrm{~N}$ fertilizer applied) and increases the risk of groundwater $\mathrm{N}$ contamination [16,17].

Because of the aforementioned critical situation, it is necessary to manage the water and $\mathrm{N}$ input to ensure the sustainable utilization of groundwater resources. To decrease the water input and limit or even halt the groundwater withdrawal under the winter wheat-summer maize system, many studies have been carried out to investigate the effects of different irrigation schedules on the performance of crops $[7,18,19]$. For example, deficit irrigation, popular in recent years, was used to minimize irrigation water use with the least crop yield reduction. With irrigation targeting critical crop growth stages, water use efficiency could be further improved and crop yield decline could be further reduced [20]. However, these still cannot stop the over-exploitation of groundwater by irrigation. Sun et al. [21] found that the minimum irrigation strategy (one irrigation for each crop) under the current cropping system can still cause groundwater decline.

Changing the current intensive cropping system by foregoing the planting of winter wheat in one or two rotation systems is a potential option to reduce the over-exploitation of groundwater in the NCP [22,23]. Based on field experiments, Meng et al. [24] found that winter wheat/summer maize-spring maize in a two-year system and spring maize, a monoculture system can reduce the use of irrigation water by $35 \%$ and $61 \%$, respectively, compared with the winter wheat and summer maize system. Based on long-term simulation using the Agricultural Production System Simulator model (APSIM), Xiao et al. [23] reported that a triple-cropping system (three crops in two years) consisting of winter wheat-summer maize and fallow early maize was the most viable alternative system as it can eliminate more than $80 \%$ of the groundwater overdraft, with only $13 \%$ compromising grain yield. Therefore, the adjustment of cropping systems with a reduction planting of a higher water-consumption crop (i.e., winter wheat) can effectively reduce the overexploitation of groundwater.

It is evident that changing the cropping system would also reduce the input of $\mathrm{N}[25,26]$. Based on field experiments in relatively short periods and on limited types of cropping systems, several studies have focused on the environmental impact of cropping system adjustment $[24,27]$. However, there is still a lack of comprehensive assessments on the long-term effects of cropping system adjustment, accompanied by changes in water and Nitrogen input, on the quality and quantity of groundwater in NCP.

An agricultural system model, in conjunction with good field data, can help with understanding the environmental and crop responses to different water and $\mathrm{N}$ inputs in the long term. Root Zone 
Water Quality Model 2 (RZWQM2), combining the RZWQM with the CERES-maize and CERES-wheat crop growth modules [28] of the Decision Support System for Agrotechnology Transfer (DSSAT) [29], is a comprehensively process-based agricultural system model. The detailed information of the model can be found in Ahuja et al. [30]. The RZWQM2 model has been widely used in rotation systems in the NCP to simulate the yield and water consumption $[7,12,13,17,31,32]$. However, integrative studies using the RZWQM2 model on yields, net consumption of groundwater, and N leaching under different cropping systems in China have not been reported.

In this study, The RZWQM2 model was applied to (1) determine the historical characteristics of the crop productivity, water consumption, and $\mathrm{N}$ leaching of the local winter wheat-summer maize rotation system; and (2) evaluate the impact of three alternative cropping systems (gradually reduce the planting frequency of winter wheat) on the crop productivity and groundwater environment compared with the winter wheat-summer maize rotation system.

\section{Materials and Methods}

\subsection{Study Site and Climate Data}

The field experiments were conducted at Luancheng Agro-Ecological Experimental Station (LAES) $\left(37^{\circ} 53^{\prime} \mathrm{N}, 114^{\circ} 41^{\prime} \mathrm{E}\right.$, elevation of $50.1 \mathrm{~m}$, and a groundwater depth of $16 \mathrm{~m}$ in 1985 and $47 \mathrm{~m}$ in 2015), which is located in the middle of the piedmont of NCP (Figure S1). The area has a semi-arid climate (Bsk type in the Köppen-Geiger climate classification) [33]. The annual mean air temperature, precipitation, and global radiation are $13.2^{\circ} \mathrm{C}$ (1971-2013), $496 \mathrm{~mm}$ (1971-2013) [6], and $5240 \mathrm{MJ} \mathrm{m}^{-2}$ [34], respectively. The predominant soil type is sandy loam [35]. The soil texture of the study area are shown in Table 1. The soil, formed principally from fluvial deposits, is classified as Fluventic Ustochrept in the USDA soil classification system. The winter wheat and summer maize rotation cropping system is most commonly used in this region. Under the current cropping system, $75 \%$ of the precipitation $(372 \mathrm{~mm})$ was in the summer maize season, which exceeds the water requirements of maize, while the rest $(124 \mathrm{~mm})$, in the winter wheat season, cannot meet the water requirements for wheat. According to the local practice, the high yield is related to intensive flood irrigation with pumped groundwater. There are 4-5 irrigations in the winter wheat season and no more than two irrigations in the summer maize season [34]. In addition, the high crop yield in the study area also depends on increasing fertilizer inputs, particularly $\mathrm{N}$ fertilizer. The forms of $\mathrm{N}$ fertilizer are ammonium bicarbonate and urea. The amount of $\mathrm{N}$ applied at the study site, following the local practice, increased from $200 \mathrm{~kg} \mathrm{ha}^{-1} \mathrm{yr}^{-1}$ in 1985 to the current $400 \mathrm{~kg} \mathrm{ha}^{-1} \mathrm{yr}^{-1}$ [4].

Table 1. The soil texture characteristics at the experimental site in the North China Plain.

\begin{tabular}{cccccc}
\hline Soil Texture & Horizon Depth $\mathbf{( c m )}$ & Bulk Density $\left(\mathbf{g ~ c m}^{-3}\right)$ & Sand & Silt & Clay \\
\hline Loam & $0-25$ & 1.29 & $40 \%$ & $40 \%$ & $20 \%$ \\
Loam & $25-40$ & 1.34 & $40 \%$ & $40 \%$ & $20 \%$ \\
Loam & $40-60$ & 1.54 & $40 \%$ & $40 \%$ & $20 \%$ \\
Loam & $60-85$ & 1.66 & $40 \%$ & $40 \%$ & $20 \%$ \\
Sandy clay loam & $85-120$ & 1.58 & $60 \%$ & $13 \%$ & $27 \%$ \\
Clay loam & $120-165$ & 1.66 & $28 \%$ & $37 \%$ & $35 \%$ \\
Sandy clay loam & $165-180$ & 1.54 & $60 \%$ & $13 \%$ & $27 \%$ \\
\hline
\end{tabular}

Historical daily climate data in 1985-2016 (including maximum and minimum temperature, precipitation, sunshine hours, precipitation, and relative humidity) were obtained from the Chinese Meteorological Administration (CMA). Sunshine hours were used to calculate solar radiation based on the Angstrom-Prescott equation [36]. 


\subsection{Field Experiments}

Field experiments, used to collect soil and crop data, including soil water content, soil $\mathrm{NO}_{3}{ }^{-} \mathrm{N}$ content, and crop phenology, yield, and leaf area index, were conducted from 2007 to 2016 at the LAES. There were two field experiments. One was for the rotation system with winter wheat and summer maize, and the other for the one crop per year system with fallow and single early sowing-summer maize (single early maize).

The field experiment of winter wheat-summer maize was conducted in three plots of $5 \times 10 \mathrm{~m}$ for two periods (2009-2013 and 2015-2016). The plots were surrounded by concrete up to a depth of $1.5 \mathrm{~m}$ to prevent the exchange of water and N. During the experimental periods, the cultivars of winter wheat and summer maize were Kenong 199 and Zhengdan 958, respectively. The planting date, harvest date, plant density, row spacing, fertilization dates and amounts, and irrigation dates and amounts are listed in Table 2. $\mathrm{N}$ fertilizer in wheat sowing was incorporated into the surface soil $(0-20 \mathrm{~cm})$ and the rest was applied accompanied by irrigation and rain. After the summer maize was harvested, the soil was plowed before sowing the winter wheat. The straw of winter wheat and summer maize was removed from the field manually, because it is impossible to use agricultural machinery in small plots, surrounded by concrete; which is not the same with the practice of the local farmers. 
Table 2. Summary of field management practices in the cropping system of winter wheat and summer maize at the Luancheng Agro-Experimental Station (LAES) in the piedmont of the North China Plain.

\begin{tabular}{|c|c|c|c|c|c|c|c|c|c|c|}
\hline \multirow{2}{*}{ Management Measures } & \multicolumn{2}{|c|}{ 2009-2010 } & \multicolumn{2}{|c|}{ 2010-2011 } & \multicolumn{2}{|c|}{ 2011-2012 } & \multicolumn{2}{|c|}{ 2012-2013 } & \multicolumn{2}{|c|}{ 2015-2016 } \\
\hline & Winter Wheat & Summer Maize & Winter Wheat & Summer Maize & Winter Wheat & Summer Maize & Winter Wheat & Summer Maize & Winter Wheat & Summer Maize \\
\hline Planting date & 1 October 2009 & 17 June 2010 & 11 October 2010 & 15 June 2011 & 7 October 2011 & 11 June 2012 & 10 October 2012 & 13 June 2012 & 10 October 2015 & 13 June 2016 \\
\hline Harvest date & 14 June 2010 & 30 September 2010 & 13 June 2011 & 2 October 2011 & 9 June 2012 & 1 October 2012 & 11 June 2012 & 1 October 2012 & 11 June 2016 & 1 October 2016 \\
\hline Planting density(seeds/ha) & $3,200,000$ & 60,000 & $3,200,000$ & 60,000 & $3,200,000$ & 60,000 & $3,200,000$ & 60,000 & $3,200,000$ & 60,000 \\
\hline Row spacing $(\mathrm{cm})$ & 20 & 60 & 20 & 60 & 20 & 60 & 20 & 60 & 20 & 60 \\
\hline Irrigation date & 25 November 2009 & & 23 November 2010 & 16 June 2011 & 16 April 2012 & 21 June 2012 & 2 December 2012 & & 12 April 2016 & \\
\hline \multirow{7}{*}{ Irrigation amounts $(\mathrm{cm})$} & 8.0 & & 8.0 & 9.4 & 12.2 & 7.3 & 3.7 & & 9.0 & \\
\hline & 15 April 2010 & & 13 April 2011 & 13 July 2011 & 3 May 2012 & & 6 April 2013 & & 8 May 2016 & \\
\hline & 10.0 & & 6.0 & 13.0 & 8.5 & & 12.9 & & 8.6 & \\
\hline & 12 May 2010 & & 2 May 2011 & & 31 May 2012 & & 7 May 2013 & & 22 May 2016 & \\
\hline & 14.7 & & 8.4 & & 12.3 & & 14.3 & & 5.1 & \\
\hline & 4 June 2010 & & 26 May 2011 & & & & 20 May 2013 & & & \\
\hline & 11.0 & & 6.0 & & & & 9.0 & & & \\
\hline \multirow{3}{*}{$\begin{array}{c}\text { Fertilization date } \\
\text { Fertilization amounts }\left(\mathrm{kg} \mathrm{N} \mathrm{ha}^{-1}\right)\end{array}$} & 1 October 2009 & & 11 October 2010 & & 7 October 2011 & 27 July 2012 & 10 October 2012 & 31 July 2013 & 10 October 2016 & \\
\hline & $\begin{array}{c}39.7 \\
\left(\mathrm{NH}^{+}-\mathrm{N}\right)\end{array}$ & & $\begin{array}{c}188.7 \\
\left(\mathrm{NH}^{+}-\mathrm{N}\right)\end{array}$ & & $\begin{array}{c}188.7 \\
\left(\mathrm{NH}^{+}{ }^{+} \mathrm{N}\right)\end{array}$ & 227.5 & 95.5 & 234.5 & 301.0 & \\
\hline & $\left(\mathrm{NH} 4^{+}-\mathrm{N}\right)$ & & $\left(\mathrm{NH}_{4}^{+}-\mathrm{N}\right)$ & & $\left(\mathrm{NH} 4^{+}-\mathrm{N}\right)$ & $($ Urea-N) & $\left(\mathrm{NH}_{4}^{+}-\mathrm{N}\right)$ & $($ Urea-N) & $\left(\mathrm{NH}_{4}^{+}-\mathrm{N}\right)$ & \\
\hline
\end{tabular}

Note that $\mathrm{NH}^{+}{ }^{+}-\mathrm{N}$ and Urea-N respectively denote Ammonium nitrogen and urea nitrogen. 
The field experiment of single early maize was conducted in three plots in 2014-2016. The plot size was $6.5 \times 5 \mathrm{~m}$ and each plot was separated by isolation strips. The management practices in 2014-2015 were as described by Xiao et al. [23]. A total of $548 \mathrm{~kg}$ urea $(252 \mathrm{~kg} \mathrm{~N})$ per hectare was incorporated into the surface soil before sowing single early maize in 2016.

Between these two experiments, the soil water content, leaf area index, crop yield, and crop phenology were measured in the two periods (2009-2013 and 2015-2016). Evapotranspiration based on Eddy Covariance observation [5] under the winter wheat-summer maize system was also used for model calibration and validation. The soil $\mathrm{NO}_{3}{ }^{-}-\mathrm{N}$ content of the different layers in the soil profile was measured from October 2015 to October 2016. The soil water content was determined by neutron probes with an interval of $10 \mathrm{~cm}$ in $0-20 \mathrm{~cm}$ and $20 \mathrm{~cm}$ in $20-180 \mathrm{~cm}$. The time interval was $5-7$ days, and there was an additional measurement after precipitation or irrigation. The leaf area index was measured every 10-15 days and the crop phenology was recorded. The soil samples were collected every 10-15 days by a manual auger, air-dried and mixed with deionized water in the ratio of 1:5, and centrifugally separated to extract the soil solutes. The soil $\mathrm{NO}_{3}{ }^{-}-\mathrm{N}$ concentration was then measured by ion chromatography (ICS-2100). In the winter wheat-summer maize experiment, the central area of $3 \times 8 \mathrm{~m}$ of each experimental plot $(5 \times 10 \mathrm{~m})$ was harvested to measure the crop yields, and ten and three representative plants were used to measure the aboveground biomasses for winter wheat and summer maize, respectively. Under the single early maize experiment, because of the isolation strip around the experimental area, measurement of the yield was based on the whole plot, and measurement of the biomass was the same for summer maize. In summary, the soil water content and crop data were collected in 2009-2013 under the winter wheat-summer maize experiment and in 2014-2015 under the single early maize experiment. And soil $\mathrm{NO}_{3}{ }^{-}-\mathrm{N}$ content was measured in 2015-2016 under winter wheat-summer maize and in 2016 under single early maize.

\subsection{RZWQM2 Model Calibration and Validation}

The RZWQM2 model integrates physical, chemical, and biological processes to simulate crop growth, and water, nutrients and pesticides movement through the root zone at a representative area of different management conditions. Evapotranspiration, runoff and water drainage out of the root zone are output items, with the inputs of precipitation and irrigation. The output items for $\mathrm{N}$ balance include denitrification, volatilization, runoff, $\mathrm{N}$ leaching out of the root zone, etc., with the inputs of $\mathrm{N}$ in rain, irrigation, fertilizer, and manure.

The calibrated model parameters involve the soil hydraulic, soil $\mathrm{N}$ transformation and crop cultivar parameters. As the RZWQM2 model developers recommended, soil hydraulic parameters should be calibrated first, followed by the $\mathrm{N}$ transformation parameters and the crop parameters [37]. A combination of trial and error and the automatic parameter adjustment method was used to implement the model calibration. Root Mean Square Error (RMSE) and Mean Relative Error (MRE) were used as the criteria for evaluating simulation results:

$$
\begin{aligned}
& M R E=\frac{1}{n} \sum_{i=1}^{n}\left(\frac{S_{i}-O_{i}}{O_{i}}\right) 100 \% \\
& R M S E=\sqrt{\frac{1}{n} \sum_{i=1}^{n}\left(S_{i}-O_{i}\right)^{2}}
\end{aligned}
$$

where $O_{\mathrm{i}}$ is the $i$ th observed value, $S_{i}$ is the $i$ th simulated value and $n$ is the number of data pairs.

Considering the experiment design and availability of the measured data, different periods of data were used to calibrate and validate the soil hydraulic, soil $\mathrm{N}$ transformation, and crop cultivar parameters. The soil hydraulic parameters were calibrated and validated based on field experiment data under the winter wheat-summer maize experiment. The data from 2009 to 2011 was selected for calibration and the data from 2011 to 2013 for validation. The soil $\mathrm{N}$ transformation parameters 
were calibrated based on the data of winter wheat-summer maize and validated based on the data of single early maize and the initial value of the parameter refers to Zhang and Ren [38]. For the winter wheat-summer maize system, crop cultivar parameters were calibrated based on the data from 2009-2011 under the winter wheat-summer maize experiment and validated using the data from 2011-2013. The crop cultivar parameters for single early maize were calibrated and validated using the single early maize experimental data in 2014 and 2015, respectively. Detailed information about the calibration and validation processes is given in Table 3.

Table 3. The process of the RZWQM2 model calibration and validation.

\begin{tabular}{cccc}
\hline \multicolumn{2}{c}{ Parameters Types } & Calibration & Validation \\
\hline \multicolumn{2}{c}{ soil hydraulic parameters } & 2009-2011 (WW-SM) & 2011-2013 (WW-SM) \\
\hline \multicolumn{2}{c}{ soil nutrient component parameters } & $2016(\mathrm{WW}-\mathrm{SM})$ & $2016(\mathrm{EM})$ \\
\hline \multirow{2}{*}{ crop cultivar parameters } & WW-SM & $2009-2011(\mathrm{WW}-\mathrm{SM})$ & $2011-2013(\mathrm{WW}-\mathrm{SM})$ \\
\cline { 2 - 4 } & EM & \multicolumn{2}{c}{ 2014-2015 (EM) } \\
\hline
\end{tabular}

Note that WW-SM and EM respectively denote the rotation system of winter wheat and summer maize and the mono-cropping system of fallow and early sowing summer maize.

\subsection{Evaluating the Impact of Alternative Cropping Systems on Groundwater Consumption and Nitrate Leaching}

The grain yield, groundwater consumption for irrigation, and $\mathrm{N}$ leaching of the local rotation system under the practical irrigation (WW-SM_pi, with practical flood irrigation) in 1985-2015 were modelled. To clarify the impact of cropping system adjustment on crop production and the environment, the model was also run under alternative cropping systems. The three alternative cropping systems were: (1) three harvests in two years, consisting of winter wheat-summer maize and fallow-early maize (WW-SM-SEM); (2) four harvests in three years, consisting of winter wheat-summer maize and double fallow-early maize (WW-SM-2SEM); and (3) a single harvest in one year, consisting of fallow and early maize. The planting frequency of winter wheat gradually decreased in the alternative cropping systems. Due to there being no records of the irrigation times and amounts of the alternative cropping systems, they were simulated with triggered auto-irrigation in the RZWQM2 model. The triggered irrigation amount and time were determined by auto-irrigation of the RZWQM2 model. Irrigation was triggered at $65 \%$ field capacity and finished at $80 \%$ field capacity in $0-100 \mathrm{~cm}$ soil profile with a minimum time interval of seven days between the double continuous irrigation events. To compare the impact of alternative cropping systems under similar conditions, to use the same field practices, including irrigation schemes, as much as possible, was needed. Therefore, the local rotation system under auto-irrigation (WW-SM_ai) was modeled as the baseline for comparison.

Detailed information on the local practices over the last 30 years was obtained from scientific research reports and experiments at the LAES, including irrigation, fertilization, crop cultivars, and tillage practice. Figure 1 shows the irrigation and precipitation in the winter wheat and summer maize growing seasons over the past 30 years (1985-2015). The amounts of $\mathrm{N}$ fertilizer applied in 1985-1990, 1991-1998, 1999-2003, and 2004-2015 period were 200, 280, 320, and $400 \mathrm{~kg} \mathrm{ha}^{-1} \mathrm{yr}^{-1}$, respectively. Twenty-five percent of the total $\mathrm{N}$ fertilizer in $\mathrm{NH}_{4}{ }^{+}-\mathrm{N}$ was applied to the surface soil layer with plowing before the winter wheat planting, while the rest, in the form of urea, was broadcast equally with irrigation or precipitation in the jointing stage of winter wheat and the V9 stage (the ninth leaf stage) of summer maize [4]. The straw of winter wheat and summer maize were removed from the field manually from October 1985 to October 1990. Winter wheat straw was crushed and left in the field as mulch, and the summer maize straw was still removed from the field manually from October 1990 to October 1998. The straw of the winter wheat and summer maize were both chopped and incorporated into the topsoil layer after October 1998 [4]. The setting of the straw treatment and $\mathrm{N}$ fertilizer application of the alternative cropping systems is consistent with WW-SM_pi (or 
WW-SM_ai). The N application amount in the SEM was set to be the same as in the summer maize season in WW-SM_pi (or WW-SM_ai). As a summary of the foregoing, the average N application rates of WW-SM_pi (or WW-SM_ai), WW-SM-SEM, WW-SM-2SEM, and SEM were 322.7, 221, 187.7, and $121 \mathrm{~kg} \mathrm{ha}^{-1} \mathrm{yr}^{-1}$, respectively. In the study area, the irrigation was mainly from groundwater. Therefore, the net consumption of the groundwater by crops was calculated through Equation (3), where NGC is the net groundwater consumption $\left(\mathrm{mm} \mathrm{yr}^{-1}\right), I$ is irrigation $\left(\mathrm{mm} \mathrm{yr}^{-1}\right)$ and $D$ is the deep drainage $\left(\mathrm{mm} \mathrm{yr}^{-1}\right)$ out of the root zone:

$$
N G C=I-D
$$

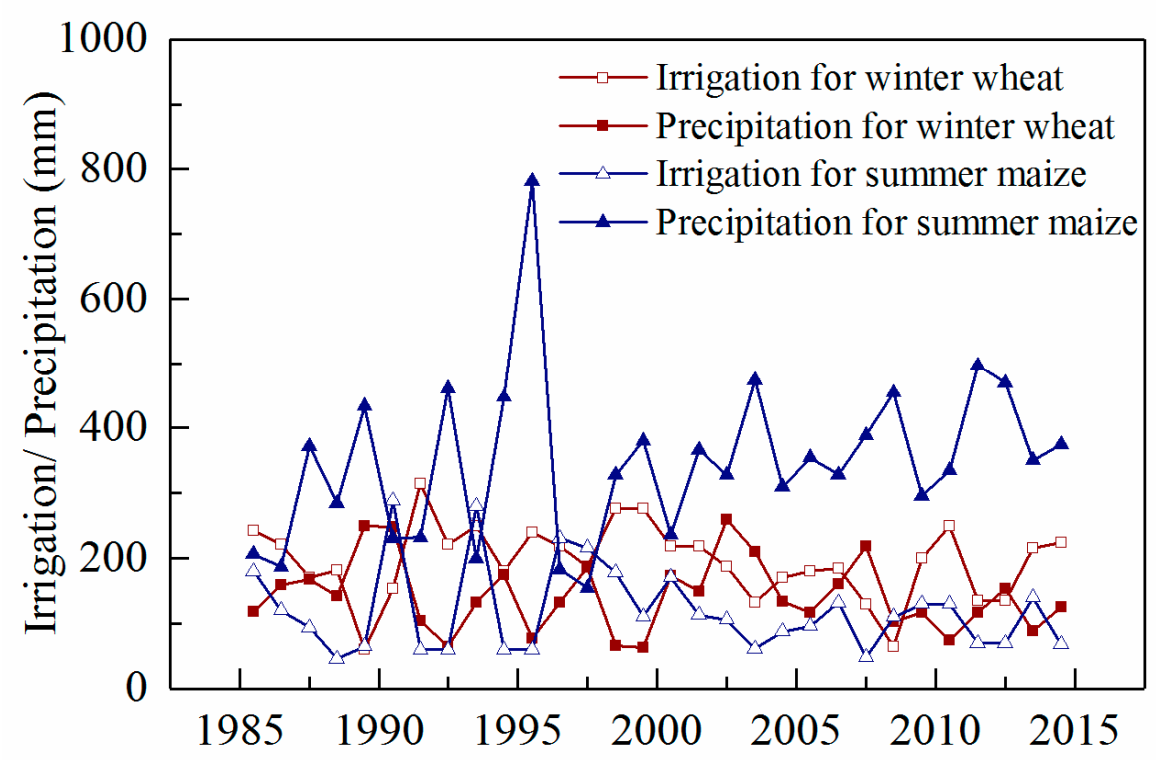

Figure 1. The amount of irrigation and precipitation in the growth period of winter wheat and summer maize at the Luancheng Agro-Experimental Station (LAES) in the North China Plain over the past 30 years (1986-2015).

\section{Results and Discussion}

\subsection{Model Performance}

As shown in Figure 2a and Table S1, in calibration, the greatest RMSE and MRE for soil water content from 0 to $180 \mathrm{~cm}$ were $0.071 \mathrm{~cm}^{3} \mathrm{~cm}^{-3}$ and $-15.34 \%$, located at $0-20 \mathrm{~cm}$, which is partially due to the lower accuracy of neutron-based measured soil water content near the ground surface [39], while other layers all had the absolute values of MRE smaller than 10\% and RMSE smaller than $0.05 \mathrm{~cm}^{3} \mathrm{~cm}^{-3}$. The RMSE and MRE of the calibration results of soil water storage (SWS) at 0-180 cm were $3.950 \mathrm{~cm}$ and $-1.47 \%$, respectively (Figure 2c). Hu et al. [13] obtained similar results with an RMSE of $5.9 \mathrm{~cm}$ for the SWS $(0-180 \mathrm{~cm})$ using the RZWQM. The RMSEs and MREs of soil water content in validation were similar to the calibration results (Figure 2b), with the greatest RMSE and MRE $0.046 \mathrm{~cm}^{3} \mathrm{~cm}^{-3}$ and $8.31 \%$ at $0-20 \mathrm{~cm}$ and $120-140 \mathrm{~cm}$, respectively (Table S1). The RMSE of the SWS $(0-180 \mathrm{~cm})$ was $3.247 \mathrm{~cm}$, with the corresponding MRE 4.66\% (Figure 2d). Statistical information on the model performance of the soil water simulation during calibration and validation is given in Table S1. Overall, the RZWQM2 model can effectively simulate soil water dynamics. 

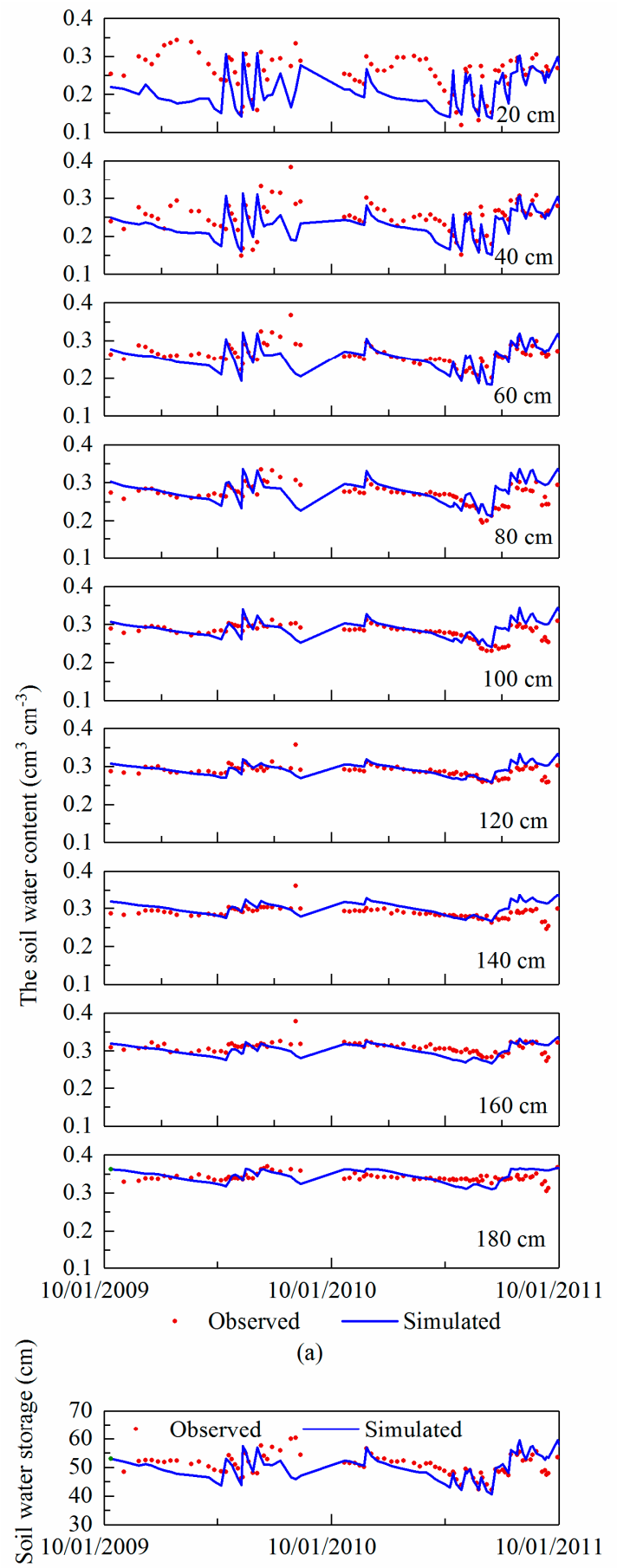

(c)

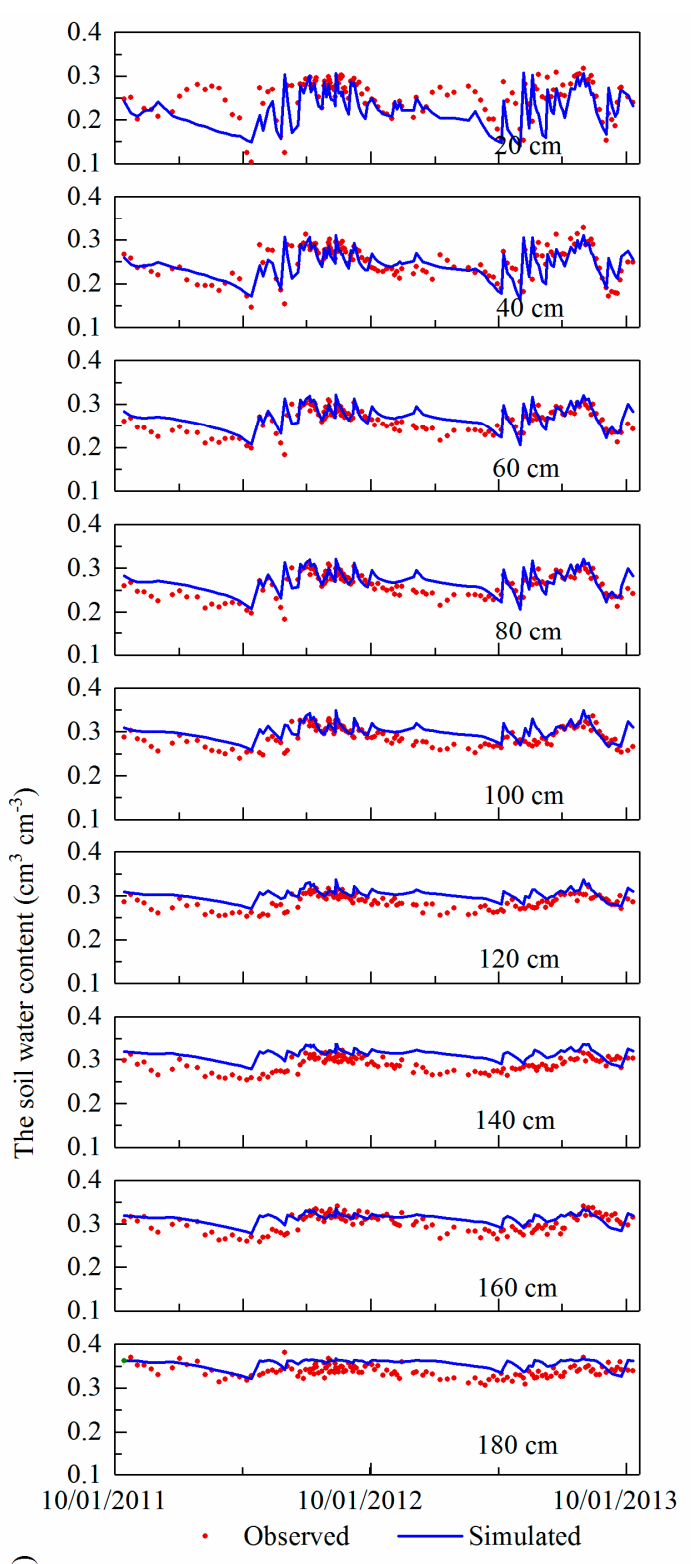

(b)

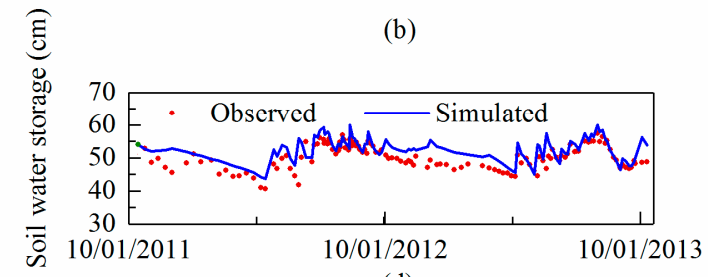

(d)

Figure 2. Comparisons of observed and simulated soil water content in the $0-180 \mathrm{~cm}$ soil profile and soil water storage for calibration $(\mathbf{a}, \mathbf{c})$ and validation $(\mathbf{b}, \mathbf{d})$.

The simulated soil $\mathrm{NO}_{3}{ }^{-}-\mathrm{N}$ storage (SNS) explained $78 \%$ of the total variance in the observation, with an RMSE of $44.57 \mathrm{~kg} \mathrm{ha}^{-1}$ and MRE of $4.37 \%$ (Figure 3a and Table S2). An RMSE of $39.00 \mathrm{~kg} \mathrm{~N}$ $\mathrm{ha}^{-1}$ (at $0-212 \mathrm{~cm}$ ) was reported in the NCP by Hu et al. [13], with the $\mathrm{N}$ balance simulated based on the RZWQM. An RMSE of $55.8 \mathrm{~kg} \mathrm{~N} \mathrm{ha}^{-1}$ and an MRE of $-22.4 \%$ under three $\mathrm{N}$ treatments were obtained by Fang et al. [12] based on RZWQM. The agreement of the soil $\mathrm{NO}_{3}{ }^{-}-\mathrm{N}$ content (SNC) in different soil layers in the observed and simulated was a little worse than that of the SNS (Figure S2). The absolute MREs for each layer ranged from 2.2 to $33.6 \%$ (Table S2) and the RMSE of each layer was an average of $7.94 \mathrm{\mu g} \mathrm{g}^{-1}$. In validation, the SNS in the soil profile that had an RMSE of $76.45 \mathrm{~kg} \mathrm{~N} \mathrm{ha}^{-1}$ 
and an MRE of 3.2\% was slightly worse than in the calibration (Figure 3b), but comparable with the previous results [12,13]. The largest and smallest absolute RMSEs of the SNC were $17.38 \mu \mathrm{g} \mathrm{g}^{-1}$ in the top layer $(0-10 \mathrm{~cm})$ and $3.87 \mathrm{\mu g} \mathrm{g}^{-1}$ at $60-80 \mathrm{~cm}$ (Table S2). The statistical information of soil $\mathrm{NO}_{3}{ }^{-}-\mathrm{N}$ simulation suggested that the model can be used to simulate the dynamic change of $\mathrm{NO}_{3}{ }^{-}-\mathrm{N}$ content in the root zone soil profile.
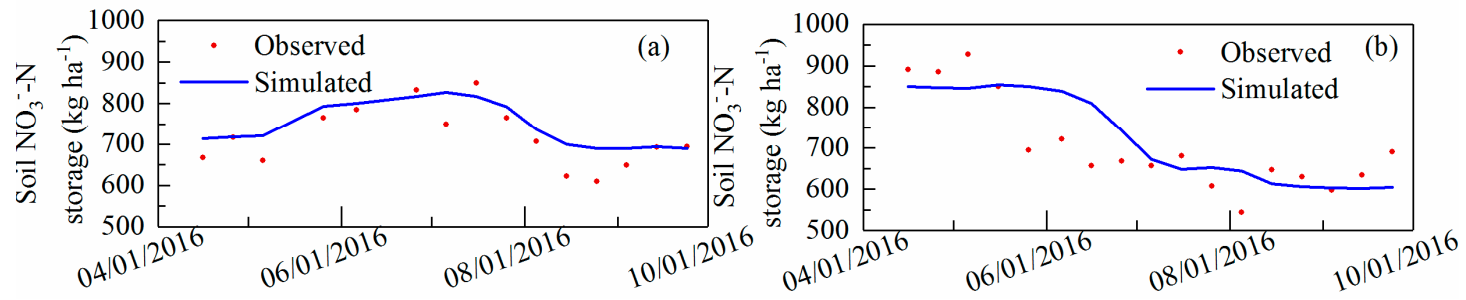

Figure 3. Comparisons of observed and simulated $\mathrm{Soil}_{\mathrm{NO}_{3}}{ }^{-} \mathrm{N}$ storage for calibration (a) and validation (b) in the $0-180 \mathrm{~cm}$ soil profile.

In the winter wheat-summer maize cropping system, the RMSEs and MREs for leaf area index (LAI), evapotranspiration (ET), and yield in calibration were 0.99 and $62.0 \%, 12.6 \mathrm{~mm}$ and $28.0 \%$, and $370.2 \mathrm{~kg} \mathrm{ha}^{-1}$ and $4.0 \%$, respectively (Table S3). The simulated LAI matched well with the observed LAI and the simulated ET matched well with the observed monthly ET by the Eddy Covariance (Figure 4). Similar to the calibration results, simulated LAI responded well to observed LAI, with RMSE and MRE of 1.01 and $14.6 \%$, and simulated ET responded well to observed ET, with RMSE and MRE of $11.3 \mathrm{~mm}$ and $30.7 \%$ (Figure 4 ) in the validation, in spite of the RMSE for LAI and MRE for ET being higher than in the calibration (Table S3). The simulated and observed crop yields followed similar trends. In general, the simulation results of the validation are comparable to the calibration.

For the single early maize, the simulated phenology matched well with the observed value. The differences between simulated crop growth stages and the observed ones were within 10 days. The deviations of the simulated yields for the two years were 44 and $-49 \mathrm{~kg} \mathrm{ha}^{-1}$ (Table 4). These results suggest that the RZWQM2 model is suitable to simulate crop (wheat and maize) growth and yield in the NCP.

Table 4. Comparisons between observed and simulated phenology and yield for single early maize.

\begin{tabular}{ccccccc}
\hline \multirow{2}{*}{ Items } & \multicolumn{3}{c}{$\mathbf{2 0 1 4}$} & \multicolumn{3}{c}{$\mathbf{2 0 1 5}$} \\
\cline { 2 - 7 } & Observed & Simulated & Deviation & Observed & Simulated & Deviation \\
\hline Sowing date (DOY) & 143 & 143 & 0 & 143 & 143 & 0 \\
Emergence date (DOY) & 148 & 148 & 0 & 148 & 148 & 0 \\
Anthesis date (DOY) & 205 & 203 & -2 & 206 & 204 & -2 \\
Maturity date (DOY) & 262 & 254 & -8 & 264 & 261 & -3 \\
Yield (kg ha ${ }^{-1}$ ) & 12,720 & 12,764 & 44 & 11,700 & 11,651 & -49 \\
\hline
\end{tabular}

Note that DOY denotes the day of year.

\subsection{Impact of the Local Rotation System on the Grain Yield and Groundwater Environment}

According to the historical record on practice management over the past 30 years (1985-2015), the grain yield, ET, deep drainage and $\mathrm{N}$ leaching of WW-SM under practical irrigation (WW-SM_pi) were simulated. The results showed that the average yield of the WW-SM_pi was 11,896.8 $\mathrm{kg} \mathrm{ha}^{-1}$, consisting of $6461.1 \mathrm{~kg} \mathrm{ha}^{-1}$ for the winter wheat and $5480.7 \mathrm{~kg} \mathrm{ha}^{-1}$ for summer maize (Table 5). The annual average ET was $692.6 \mathrm{~mm}$, including $368.1 \mathrm{~mm}$ for winter wheat and 324.5 for summer maize, respectively (Figure 5a). The result was similar to a nearly 10-year annual ET in the WW-SM_pi based on the eddy covariance observation, which had a total of $690 \mathrm{~mm}$ with $400 \mathrm{~mm}$ in the winter wheat and $290 \mathrm{~mm}$ in the summer maize [5]. The annual average deep drainage was $90.7 \mathrm{~mm}$. Xiao et al. [23] 
found that the annual average deep drainage (1981-2015) of the WW-SM with auto-irrigation was $142 \mathrm{~mm}$ based on the simulation results of the APSIM model, with higher irrigation amount $(400 \mathrm{~mm})$ than it in this modeling. Many studies have also investigated deep drainage under similar WW-SM_pi in the NCP $[6,40,41]$. These studies reported that the deep drainage ranged from $67 \mathrm{~mm} \mathrm{yr}^{-1}$ to $200 \mathrm{~mm} \mathrm{yr}^{-1}$, which is closely related to the irrigation amount. In this study, the deep drainage was $90.7 \mathrm{~mm} \mathrm{yr}^{-1}$, which was less than the groundwater extraction for irrigation $\left(317.6 \mathrm{~mm} \mathrm{yr}^{-1}\right)$. The average annual net consumption of the groundwater was $226.9 \mathrm{~mm}$ in the last 30 years, primarily in the winter wheat season (Figure 5c), which was approximately equal to the difference between precipitation and ET determined by Shen et al. [9].
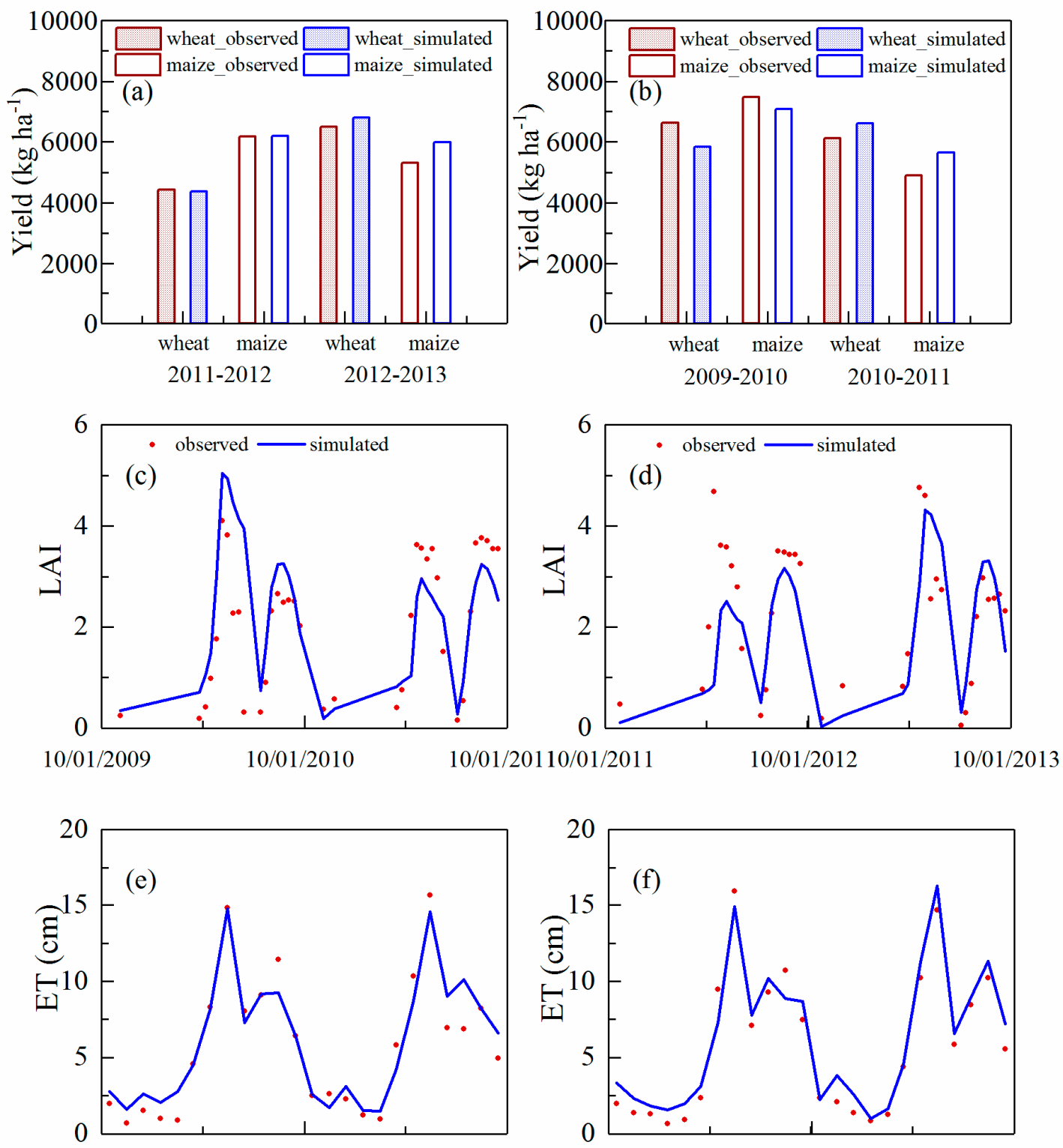

$10 / 01 / 2009$

$10 / 01 / 2010$

$10 / 01 / 201110 / 01 / 2011$

$10 / 01 / 2012$

$10 / 01 / 2013$

Figure 4. Comparisons of observed and simulated crop yield, leaf area index (LAI), and evapotranspiration (ET) for calibration $(\mathbf{a}, \mathbf{c}, \mathbf{e})$ and validation $(\mathbf{b}, \mathbf{d}, \mathbf{f})$ of winter wheat and summer maize. 
Table 5. The simulated average of yields, water balance, and $\mathrm{NO}_{3}{ }^{-}-\mathrm{N}$ leaching under different cropping systems over the past 30 years (1985-2015).

\begin{tabular}{|c|c|c|c|c|c|}
\hline Items & WW-SM_pi & WW-SM_ai & WW-SM-SEM & WW-SM-2SEM & SEM \\
\hline Yield $\left(\mathrm{kg} \mathrm{ha}^{-1} \mathrm{yr}^{-1}\right)$ & $11,896.8$ & $12,764.3$ & $11,204.9$ & $10,223.1$ & 8973.4 \\
\hline Evapotranspiration (ET, $\mathrm{mm} \mathrm{yr}^{-1}$ ) & 692.6 & 739.2 & 602.6 & 565.8 & 471.4 \\
\hline Precipitation $\left(\mathrm{mm} \mathrm{yr}^{-1}\right)$ & 490.8 & 490.8 & 490.8 & 490.8 & 490.8 \\
\hline Irrigation $\left(\mathrm{mm} \mathrm{yr}^{-1}\right)$ & 317.6 & 390.8 & 250.5 & 209.8 & 108.5 \\
\hline Drainage $\left(\mathrm{mm} \mathrm{yr}^{-1}\right)$ & 90.7 & 91.5 & 98.7 & 99.1 & 102.0 \\
\hline $\begin{array}{l}\text { Net consumption of groundwater } \\
\qquad\left(\mathrm{mm} \mathrm{yr}^{-1}\right)\end{array}$ & 226.9 & 299.3 & 151.8 & 110.7 & 6.5 \\
\hline $\mathrm{NO}_{3}{ }^{-}-\mathrm{N}$ leaching $\left(\mathrm{kg} \mathrm{N} \mathrm{ha}^{-1} \mathrm{yr}^{-1}\right)$ & 79.7 & 93.4 & 43.4 & 30.3 & 9.7 \\
\hline
\end{tabular}

Note that WW-SM_pi denotes local winter wheat-summer maize rotation system, with two harvests in one year under practical irrigation. WW-SM_ai, WW-SM-SEM, WW-SM-2SEM, and SEM, respectively, denote local winter whea-summer maize, with two harvests in one year; the winter wheat-summer maize and fallow-early maize system rotation system, with three harvests in two years; the winter wheat-summer maize and double fallow-early maize system, with four harvests in three years; and the single early maize system with one harvest per year under auto-irrigation.
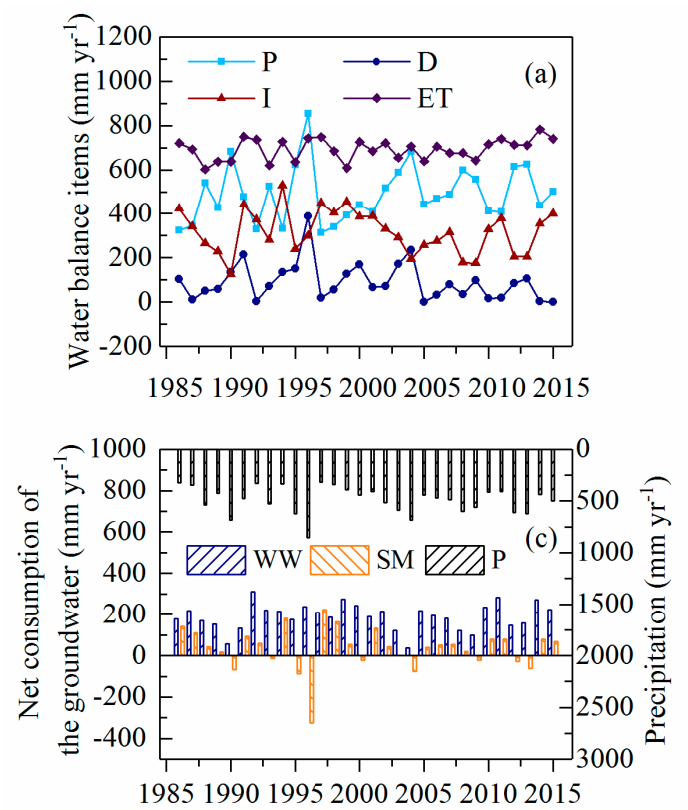

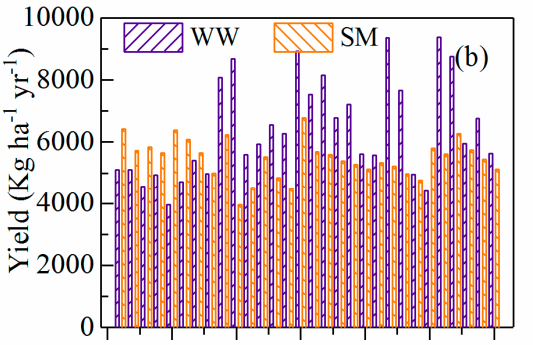

1985199019952000200520102015

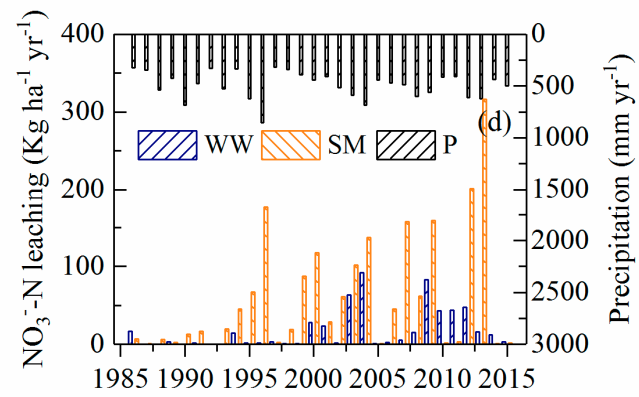

Figure 5. The results of water balance (a), yield (b), groundwater consumption (c) and $\mathrm{NO}_{3}{ }^{-}-\mathrm{N}$ leaching (d) of local rotation system of winter wheat and summer maize under practical irrigation (WW-SM_pi) over the past 30 years (1985-2015). P, I, D, ET, WW, and SM, respectively, denote precipitation, irrigation, drainage, evapotranspiration, winter wheat, and summer maize.

The $\mathrm{NO}_{3}{ }^{-}-\mathrm{N}$ leaching increased with the increase of $\mathrm{N}$ fertilizer application amount (Figure $5 \mathrm{~d}$ ). More precipitation and irrigation could result in more drainage, accompanying excessive $\mathrm{N}$ leaching. Owing to the lower precipitation in the winter wheat growing season, the deep drainage was smaller compared with the summer maize growing season. Therefore, $\mathrm{N}$ leaching mainly occurred in the growth season of the summer maize (Figure $5 \mathrm{~d}$ ) $[12,13,17,42,43]$. The annual average amount of $\mathrm{N}$ leaching was $79.7 \mathrm{~kg} \mathrm{ha}^{-1}$ (about $25 \%$ of the annual average $\mathrm{N}$ application amount), which is similar to the results of $\mathrm{Hu}$ et al. [13]. N's travel time through the deep vadose zone ranged between decades and centuries; however, anthropogenic $\mathrm{N}$ is expected to reach the aquifer in the near future in intensively irrigated areas [44]. Thus, $\mathrm{N}$ leaching out of the root zone poses a huge potential threat in terms groundwater contamination. 


\subsection{Impact of the Alternative Cropping Systems on the Groundwater Environment}

Compared with the WW-SM_pi, WW-SM_ai increased the irrigation amount by $73.2 \mathrm{~mm} \mathrm{yr}^{-1}$. The mean yield, ET, and deep drainage under the WW-SM_ai were $12,764.3 \mathrm{~kg} \mathrm{ha}^{-1} \mathrm{yr}^{-1}, 739.2 \mathrm{~mm} \mathrm{yr}{ }^{-1}$, and $91.5 \mathrm{~mm} \mathrm{yr}^{-1}$, respectively. The average $\mathrm{N}$ leaching under WW-SM_ai was $93.4 \mathrm{~kg} \mathrm{ha}^{-1} \mathrm{yr}^{-1}$, an increase of $13.7 \mathrm{~kg} \mathrm{ha}^{-1} \mathrm{yr}^{-1}$ compared with WW-SM_pi, which could be attributed to the increase in irrigation (Table 5). These results indicate that water is also an important limiting factor for crop production in NCP [23].

For local rotation system and alternative cropping systems under auto-irrigation, because of the interannual variability of weather factors, there was significant interannual variability in the yields, ET, net consumption of groundwater, and $\mathrm{N}$ leaching (Figure 6a). The accumulated amounts of irrigation, deep drainage, $\mathrm{N}$ leaching and net consumption of groundwater are shown in Figure $6 \mathrm{~b}$. The differences in deep drainage were very small under the four cropping systems, while the accumulative amounts of $\mathrm{N}$ leaching were significantly different, especially after 1995, which could be explained by the lower $\mathrm{N}$ fertilizer application before 1990 (the average annual $\mathrm{N}$ fertilizer application amount was $200 \mathrm{~kg}$ ha $^{-1}$ under WW-SM_ai). After 1990, the amount of $\mathrm{N}$ fertilizer application gradually increased to $400 \mathrm{~kg} \mathrm{ha}^{-1}$. Fang et al. [12] reported that the crop yield did not increase with the $\mathrm{N}$ fertilizer application under the WW-SM when the $\mathrm{N}$ fertilizer application was more than $200 \mathrm{~kg} \mathrm{ha}^{-1}$, which indicated that the $\mathrm{N}$ uptake by the crop did not increase. The increase in $\mathrm{N}$ application and no significant variation of the $\mathrm{N}$ uptake by the crop (unchanged yield) contributed to the increased $\mathrm{N}$ accumulation in the root zone. Therefore, the $\mathrm{N}$ leaching, accompanied by drainage of precipitation and irrigation, would increase. Thus, the differences in nitrate leaching under the four cropping systems resulted from the variation in the nitrogenous fertilizer application [26].

The net consumption of groundwater differed greatly in the four cropping systems under automatic irrigation. And they were all more than zero, which mean that the groundwater is overexploited. Because of lateral recharge from the Taihang Mountains Front (113 $\mathrm{mm} \mathrm{yr}^{-1}$ ) [45], WW-SM-2SEM and SEM, with a net consumption of groundwater of $110.7 \mathrm{~mm}$ and $6.5 \mathrm{~mm}$, respectively, could probably halt the groundwater level decline. If the water supply from the South-North Water Transfer project $\left(41 \mathrm{~mm} \mathrm{yr}^{-1}\right)$ [46] in the study area is taken into consideration, the WW-SM-SEM, with a net consumption of groundwater of $151.8 \mathrm{~mm}$, could also prevent the decline of the water table.

Comprehensively evaluating the impact of the cropping system adjusting on the yields, groundwater consumption, and N leaching in the NCP is of great importance. Compared with the local rotation system (WW-SM_ai), the amounts of irrigation and $\mathrm{N}$ fertilizer for the alternative cropping systems of WW-SM-SEM, WW-SM-2SEM, and EM decreased by $35.9 \%, 46.3 \%$, and $72.2 \%$ and $31.5 \%, 41.8 \%$, and $62.5 \%$, respectively. The yields, ET, net consumption of groundwater, and N leaching also decreased under the three alternative cropping systems. The yields decreased by $12.2 \%, 19.9 \%$, and $29.7 \%$, while the ET decreased by $18.5 \%, 23.5 \%$, and $36.2 \%$. The net consumption of groundwater decreased by $49.3 \%, 63.0 \%$, and $89.6 \%$, and the $\mathrm{N}$ leaching decreased by $53.5 \%, 67.5 \%$, and $89.6 \%$, respectively (Figure 7). The reductions in the yields of the alternative cropping systems were less than $30 \%$, while the decrease in the net consumption of groundwater and $\mathrm{N}$ leaching was more than $40 \%$.

The local rotation system had the most significant advantage in terms of grain production and made a great contribution to the food supply in the study region and even in the whole of China [47,48]. However, The local rotation system consumed significant groundwater resources and resulted in considerable $\mathrm{N}$ leaching, which caused a continuous decline in the groundwater level and posed a threat to the environment [42,45]. In addition, the NCP experienced climate change in the form of a

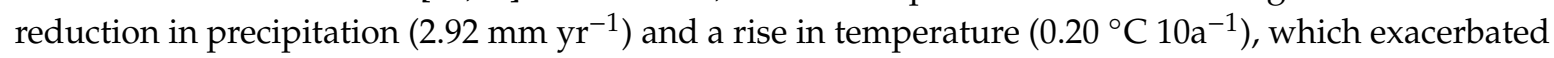
the water shortage crisis $[49,50]$. Therefore, it is urgent to reduce the consumption of groundwater by irrigation and lessen the potential contamination of the groundwater caused by the application of large amounts of $\mathrm{N}$ fertilizer. 

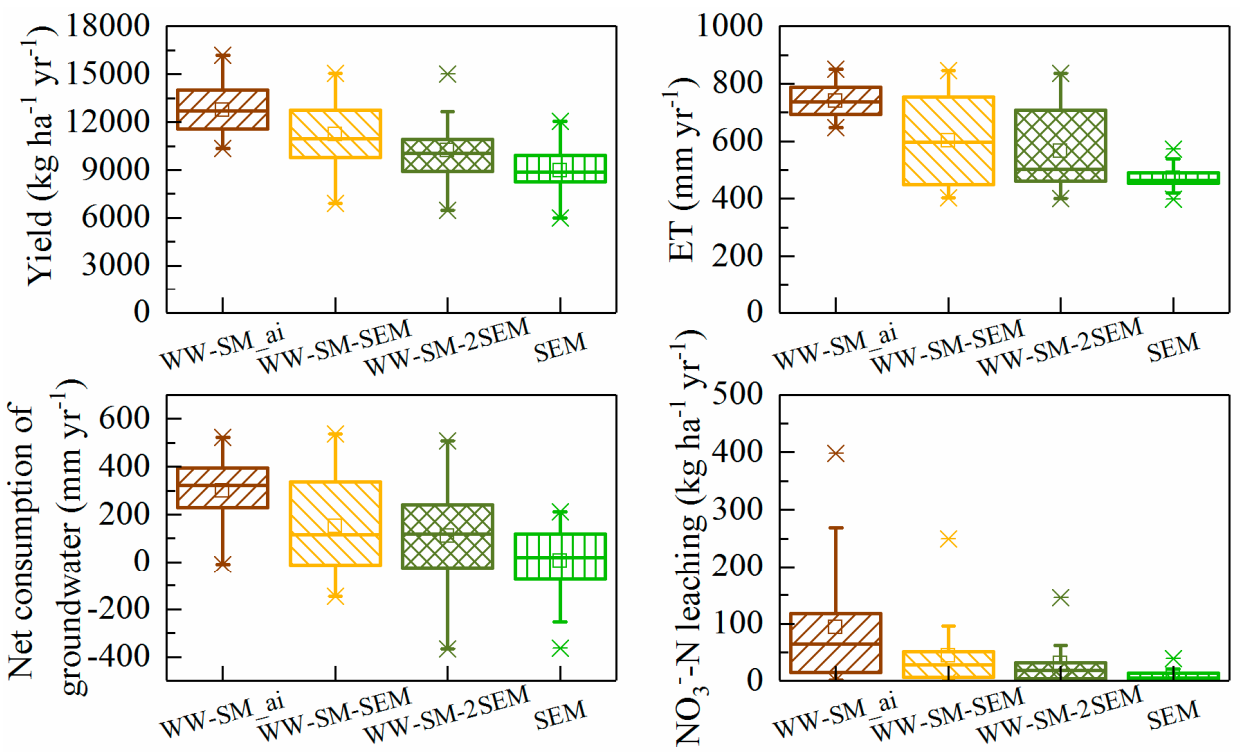

EZJWw-SM_ai

DWW-SM-SEM

WW-SM-2SEM Ш

(a)
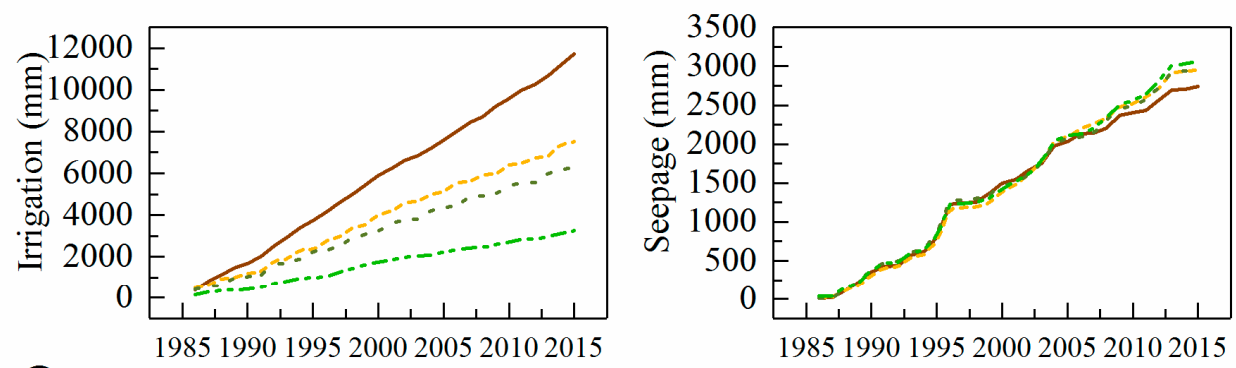

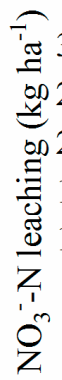
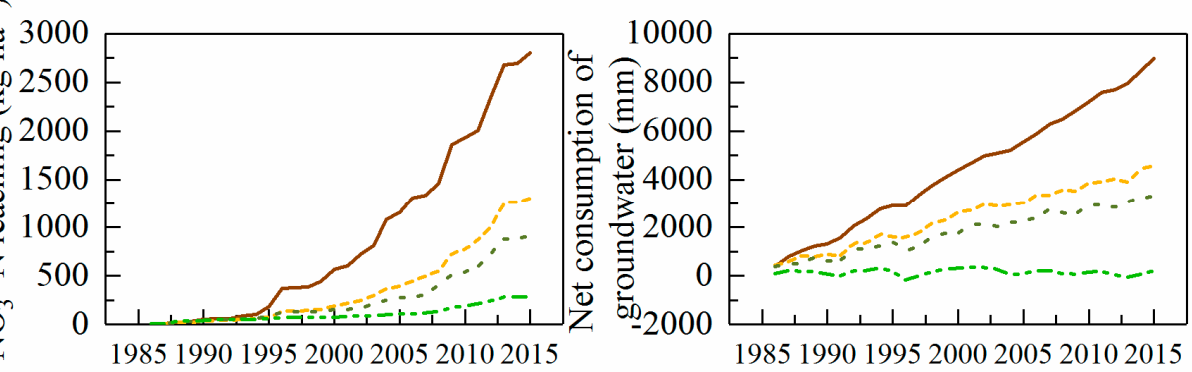

WW-SM_ai

.. - WW-SM-2SEM -..... SEM

(b)

Figure 6. Box plots (a) of the simulated yield, evapotranspiration (ET), net consumption of groundwater, and $\mathrm{NO}_{3}{ }^{-} \mathrm{N}$ leaching; and graphs (b) of accumulation of the simulated seepage, irrigation, net consumption of groundwater, and $\mathrm{NO}_{3}{ }^{-}-\mathrm{N}$ leaching of the local rotation system, WW-SM_ai, and three alternative cropping systems, WW-SM-SEM, WW-SM-2SEM, and SEM by the RZWQM2 model under auto-irrigation. Note: WW-SM_ai, WW-SM-SEM, WW-SM-2SEM, and SEM are the winter wheat-summer maize rotation system, with two harvests in one year; the winter wheat-summer maize and fallow-early maize system, with three harvests in two years; the winter wheat-summer maize and double fallow-early maize system, with four harvests in three years; and the single early maize system with one harvest per year. 


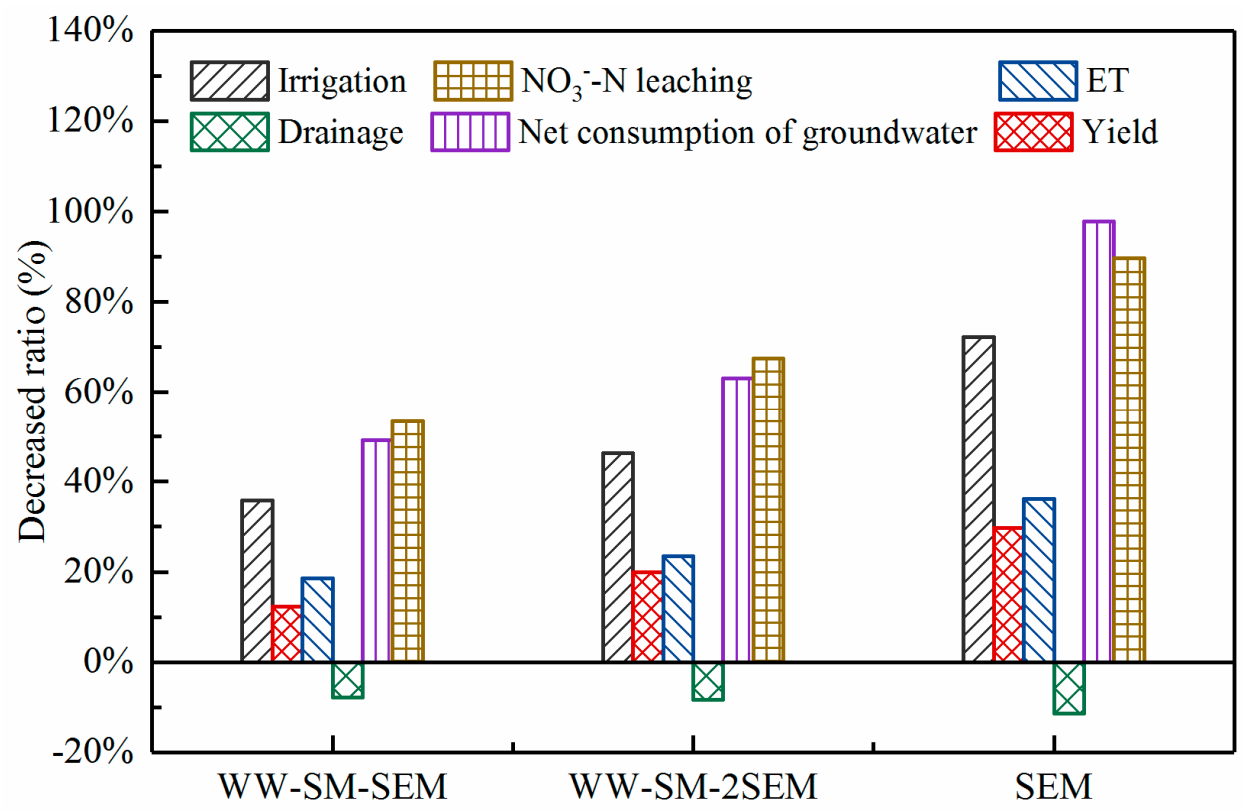

Figure 7. The decreased ratio of yield, evapotranspiration (ET), drainage, irrigation, net consumption of groundwater, and $\mathrm{NO}_{3}{ }^{-}-\mathrm{N}$ leaching of the three alternative cropping systems (WW-SM-SEM, WW-SM-2SEM, and SEM), compared with the local rotation system (WW-SM_ai). WW-SM-SEM, WW-SM-2SEM, and SEM are the winter wheat-summer maize and fallow-early maize system, with three harvests in two years; the winter wheat-summer maize and double fallow-early maize system, with four harvests in three years; and the single early maize system with one harvest per year.

The yields of the alternative cropping systems (WW-SM-SEM, WW-SM-2SEM, and SEM) with a smaller reduction could be explained by the yield advantage of the early-sowing maize [23]. The grain production of the early-sowing maize $\left(8973.4 \mathrm{~kg} \mathrm{ha}^{-1}\right.$, Table 5) may be further improved through increasing planting density and improving other management measures [24]. Cui et al. [51] assessed the environmental and economic impacts of the cropping system shift from winter wheat-summer maize to single maize and concluded that the single maize would be an effective countermeasure to resolve environmental pressures. However, as the primary staple food crop, not only in the local area but also in the whole country, wheat is expected to increase in yield as we select suitable traits for the increasing temperatures of climate change [52]. Careful consideration should be given before abandoning the planting of winter wheat entirely.

\subsection{Impact of the Alternative Cropping Systems on the Regional Crop Yields}

Since the 1970s, the rotation of winter wheat and summer maize has gradually become the dominant system, as a result of the pressure of grain production and the increase of the pumped wells in the NCP. In the past few decades, this rotational cropping system had made a great contribution to food production in this region and even in the whole of China $[53,54]$, but it also led to serious groundwater overexploitation and a poor water environment $[14,46]$. In order to alleviate the crisis of water resources and the environment, Luo et al. [55] explored the influence of cropping system adjustment on regional grain yield based on APSIM modeling in the Beijing-Tianjin-Hebei plain and found that the total yield decreased gradually from WW-SM (29.78 billion $\left.\mathrm{kg} \mathrm{yr}^{-1}\right)$ to WW-SM-SEM (27.50 billion $\mathrm{kg} \mathrm{yr}^{-1}$ ), WW-SM-2SEM (26.74 billion $\mathrm{kg} \mathrm{yr}^{-1}$ ), and SEM (25.22 billion kg yr${ }^{-1}$ ). The yields of the alternative cropping systems were 7.7-15.3\% lower than with WW-SM_ai because of the decrease in the yield of wheat. However, along with economic development, people's dietary structure has changed dramatically, which has reduced the demand for staple crops and increased the consumption of animal protein, also increasing the demand for maize for use as animal feed [24,56]. These alterations increase the promotion potential of alternative cropping systems. 
In China, food production is mainly distributed in the northeastern region, the northwestern region, and the NCP region, which are characterized by scarce water resources $[48,57]$. From the perspective of virtual water theory, a spatial mismatch between current grain production intensity and water resources in China leads the flow of virtual water from the north, for example in the NCP, where water is scarce, to the south, where water is relatively abundant. These flows further aggravated the water shortage in the NCP. In the future, it is needed to change the situation of the NCP as China's granary gradually, so that grain production in the NCP only needs to be self-sufficient, to reduce the pressure of food production on water resources [58].

\subsection{Uncertainty and Limitations}

In this study, the uncertainty in the results is mainly from model parameters. For the experiment, the crop cultivars of winter wheat and summer maize were "Kenong 199" and "Zhengdan 958". In the past 30 years, the cultivars of winter wheat and summer maize changed substantially [4]. However, because of the absence of other crop cultivar parameters in the past, changes in crop cultivar are not taken into account. This problem was also faced in previous studies, whose authors made the same assumption $[23,26,55]$. In addition, under different cropping systems, the field management practice is different, which may cause changes in soil properties and lead to changes in soil parameters. These changes were not considered in this study. Moreover, in the simulation of WW-SM, WW-SM-SEM, WW-SM-2SEM, and SEM, the setting of the irrigation is auto-irrigation, because of no actual records. In any case, the focus is to carry out a comparative study, in which the impact of alternative cropping systems on the yield, water consumption, and $\mathrm{N}$ leaching is compared. Despite the assumptions mentioned above, this study can provide a reference for the grain yields and environmental effects of alternative cropping systems in the region.

The limitation of this study is that the research is based on the field scale. Although it can provide a reference for cropping system adjustment to balance the crop production and a sustainable groundwater environment, there also need to be further regional analyses due to differences in climate, hydrology, soil, and other factors, even taking future climate change into consideration. Some studies have reported that increasing temperatures would have a negative impact on maize production in the future [59-61]. Therefore, in the face of climate change (involving changes in temperature and precipitation), more sustainable alternative cropping systems need to be further investigated to balance the relationship between the grain production and the water environment in the future.

\section{Conclusions}

The winter wheat-summer maize rotation system consumes a lot of groundwater and posed a serious environmental threat. To achieve sustainable agricultural production and water resources utilization, this study investigated crop production, water consumption, and $\mathrm{N}$ leaching in the local rotation system and alternative cropping systems over the past 30 years using the RZWQM2 model. Under the intensive rotation system with the local practice (including irrigation, fertilization and crop straw treatment), the annual average net consumption of groundwater was $226.9 \mathrm{~mm}$, which led to a continuous decline of the water table. In addition, $24.7 \% \mathrm{~N}$ input was lost by leaching, mainly in the summer maize season, because of heavy rainfall and $\mathrm{N}$ accumulation after the wheat harvest.

Compared with the local rotation system (WW-SM_ai), the three alternative cropping systems WW-SM-SEM, WW-SM-2SEM, and SEM could reduce the net consumption of groundwater by $49.3 \%$, $63.0 \%$, and $97.8 \%$, respectively. And $\mathrm{N}$ leaching of the alternative systems WW-SM-SEM, WW-SM-2SEM, and SEM was reduced by $53.5 \%, 67.5 \%$, and $89.6 \%$, respectively, while the grain production lost was less than $30 \%$. In summary, these alternative cropping systems with decreasing the planting frequency of winter wheat can reduce groundwater overexploitation and $\mathrm{N}$ contamination with a relatively limited reduction in grain yields, which will be effective in regional sustainbale groundwater management and more friendly envrioment. 
Supplementary Materials: The following are available online at http://www.mdpi.com/2073-4395/10/11/1635/s1, Figure S1: A map showing the location of the North China Plain (NCP) in China (inset plate on the left) and the Luancheng Agro-Ecological Experimental Station (LAES) (main plate on the left) in the plain, Figure S2: Comparisons of observed and simulated soil nitrate content by the RZWQM2 model for calibration (a) and validation (b) in the 0-180 cm soil profile, Table S1: The RMSEs and MREs between the observed and simulated soil water content in different soil layers and soil water storage (SWS) in the total profile by the RZWQM2 model, Table S2: The RMSEs and MREs between the observed and simulated soil nitrate-nitrogen content (SNC) in different soil layers and soil nitrate -nitrogen storage (SNS) in the total profile by the RZWQM2 model, Table S3: The RMSEs and MREs between the observed and simulated leaf area index (LAI), yield and biomass of winter wheat and summer maize by the RZWQM2 model, and the results of the calibrated model parameters of the RZWQM2 model.

Author Contributions: Conceptualization, L.M. and Y.S.; methodology, M.L. and L.M.; validation, M.L.; data curation, M.L. and L.W.; writing—original draft preparation, M.L., and L.M.; writing-M.L., and L.M.; supervision, Y.S.; and funding acquisition, L.M. and Y.S. All authors have read and agreed to the published version of the manuscript.

Funding: The Research and Development Plan (2018YFC0406501), the Hebei Key Research and Development Plan (18397002D), and the Natural Scientific Foundation of China (NSFC, grant nos. 41930865 and 4151101201).

Acknowledgments: We thank Qianjing Jiang for her guidance in using the RZWQM2 model.

Conflicts of Interest: The authors declare that they have no known competing financial interests or personal relationships that could influence the work reported in this paper.

\section{References}

1. Yuan, Z.; Shen, Y. Estimation of agricultural water consumption from meteorological and yield data: A case study of Hebei, North China. PLoS ONE 2013, 8, e58685. [CrossRef] [PubMed]

2. Wang, S.; Wei, S.; Liang, H.; Zheng, W.; Li, X.; Hu, C.; Currell, M.J.; Zhou, F.; Min, L. Nitrogen stock and leaching rates in a thick vadose zone below areas of long-term nitrogen fertilizer application in the North China Plain: A future groundwater quality threat. J. Hydrol. 2019, 576, 28-40. [CrossRef]

3. Zheng, C.; Liu, J.; Cao, G.; Kendy, E.; Wang, H.; Jia, Y. Can China Cope with Its Water Crisis?-Perspectives from the North China Plain. Ground Water 2010, 48, 350-354. [CrossRef] [PubMed]

4. Zhang, X.; Chen, S.; Sun, H.; Shao, L.; Wang, Y. Changes in evapotranspiration over irrigated winter wheat and maize in North China Plain over three decades. Agric. Water Manag. 2011, 98, 1097-1104. [CrossRef]

5. Zhang, Y.; Lei, H.; Zhao, W.; Shen, Y.; Xiao, D. Comparison of the water budget for the typical cropland and pear orchard ecosystems in the North China Plain. Agric. Water Manag. 2018, 198, 53-64. [CrossRef]

6. Min, L.; Shen, Y.; Pei, H. Estimating groundwater recharge using deep vadose zone data under typical irrigated cropland in the piedmont region of the North China Plain. J. Hydrol. 2015, 527, 305-315. [CrossRef]

7. Fang, Q.; Ma, L.; Yu, Q.; Ahuja, L.R.; Malone, R.W.; Hoogenboom, G. Irrigation strategies to improve the water use efficiency of wheat-maize double cropping systems in North China Plain. Agric. Water Manag. 2010, 97, 1165-1174. [CrossRef]

8. Yuan, Z.; Yan, D.; Yang, Z.; Yin, J.; Breach, P.; Wang, D. Impacts of climate change on winter wheat water requirement in Haihe River Basin. Mitig. Adapt. Strateg. Glob. Chang. 2014, 21, 677-697. [CrossRef]

9. Shen, Y.; Zhang, Y.; Scanlon, B.R.; Lei, H.; Yang, D.; Yang, F. Energy/water budgets and productivity of the typical croplands irrigated with groundwater and surface water in the North China Plain. Agric. For. Meteorol. 2013, 181, 133-142. [CrossRef]

10. Zheng, L.; Pan, Y.; Gong, H.; Huang, Z.; Zhang, C. Comparing groundwater storage changes in two main grain producing areas in China: Implications for sustainable agricultural water resources management. Remote Sens. 2020, 12, 2151. [CrossRef]

11. Galloway, J.N.; Dentener, F.J.; Capone, D.G.; Boyer, E.W.; Howarth, R.W.; Seitzinger, S.P.; Asner, G.P.; Cleveland, C.C.; Green, P.A.; Holland, E.A.; et al. Nitrogen cycles: Past, present, and future. Biogeochemistry 2004, 70, 153-226. [CrossRef]

12. Fang, Q.; Ma, L.; Yu, Q.; Malone, R.W.; Saseendran, S.A.; Ahuja, L.R. Modeling nitrogen and water management effects in a wheat-maize double-cropping system. J. Environ. Qual. 2008, 37, 1466-1479. [CrossRef] [PubMed]

13. Hu, C.; Saseendran, S.A.; Green, T.R.; Ma, L.; Li, X.; Ahuja, L.R. Evaluating nitrogen and water management in a double-cropping system using RZWQM. Vadose Zone J. 2006, 5, 493-505. [CrossRef] 
14. Ju, X.; Xing, G.; Chen, X.; Zhang, S.; Zhang, L.; Liu, X.; Cui, Z.; Yin, B.; Peter, C.; Zhu, Z.; et al. Reducing environmental risk by improving $\mathrm{N}$ management in intensive Chinese agricultural systems. Proc. Natl. Acad. Sci. USA 2009, 106, 3041-3046. [CrossRef] [PubMed]

15. Ju, X.; Zhang, C. Nitrogen Cycling and Environmental Impacts in Upland Agricultural Soils in North China: A Review. J. Integr. Agric. 2017, 16, 2848-2862. [CrossRef]

16. Ju, X.; Liu, X.; Zhang, F.; Roelcke, M. Nitrogen fertilization, foil nitrate accumulation, and policy recommendations in several agricultural regions of China. AMBIO J. Hum. Environ. 2004, 33, 300-305. [CrossRef] [PubMed]

17. Sun, M.; Huo, Z.; Zheng, Y.; Dai, X.; Feng, S.; Mao, X. Quantifying long-term responses of crop yield and nitrate leaching in an intensive farmland using agro-eco-environmental model. Sci. Total Environ. 2018, 613-614, 1003-1012. [CrossRef]

18. Zhang, X.; Pei, D.; Chen, S.; Sun, H.; Yang, Y. Performance of Double-Cropped Winter Wheat-Summer Maize under Minimum Irrigation in the North China Plain. Agron. J. 2006, 98, 1620-1626. [CrossRef]

19. Sun, H.; Zhang, X.; Chen, S.; Shao, L. Performance of a Double Cropping System under a Continuous Minimum Irrigation Strategy. Agron. J. 2014, 106, 281-289. [CrossRef]

20. Zhang, X.; Wang, S.; Sun, H.; Chen, S.; Shao, L.; Liu, X. Contribution of cultivar, fertilizer and weather to yield variation of winter wheat over three decades: A case study in the North China Plain. Eur. J. Agron. 2013, 50, 52-59. [CrossRef]

21. Sun, H.; Zhang, X.; Wang, E.; Chen, S.; Shao, L. Quantifying the impact of irrigation on groundwater reserve and crop production-A case study in the North China Plain. Eur. J. Agron. 2015, 70, 48-56. [CrossRef]

22. Van Oort, P.A.J.; Wang, G.; Vos, J.; Meinke, H.; Li, B.G.; Huang, J.K.; van der Werf, W. Towards groundwater neutral cropping systems in the Alluvial Fans of the North China Plain. Agric. Water Manag. 2016, 165, 131-140. [CrossRef]

23. Xiao, D.; Shen, Y.; Qi, Y.; Moiwo, J.P.; Min, L.; Zhang, Y.; Guo, Y.; Pei, H. Impact of alternative cropping systems on groundwater use and grain yields in the North China Plain Region. Agric. Syst. 2017, 153, 109-117. [CrossRef]

24. Meng, Q.; Sun, Q.; Chen, X.; Cui, Z.; Yue, S.; Zhang, F.; Römheld, V. Alternative cropping systems for sustainable water and nitrogen use in the North China Plain. Agric. Ecosyst. Environ. 2012, 146, 93-102. [CrossRef]

25. Gao, B.; Ju, X.; Su, F.; Meng, Q.; Oenema, O.; Christie, P.; Chen, X.; Zhang, F. Nitrous oxide and methane emissions from optimized and alternative cereal cropping systems on the North China Plain: A two-year field study. Sci. Total Environ. 2014, 472, 112-124. [CrossRef]

26. Zhao, Z.; Qin, X.; Wang, Z.; Wang, E. Performance of different cropping systems across precipitation gradient in North China Plain. Agric. For. Meteorol. 2018, 259, 162-172. [CrossRef]

27. Gao, B.; Ju, X.; Meng, Q.; Cui, Z.; Christie, P.; Chen, X.; Zhang, F. The impact of alternative cropping systems on global warming potential, grain yield and groundwater use. Agric. Ecosyst. Environ. 2015, 203, 46-54. [CrossRef]

28. Jones, J.W.; Hoogenboom, G.; Porter, C.H.; Boote, K.J.; Batchelor, W.D.; Hunt, L.A.; Wilkens, P.W.; Singh, U.; Gijsman, A.J.; Ritchie, J.T. DSSAT cropping system model. Eur. J. Agron 2003, 18, 235-265. [CrossRef]

29. Hoogenboom, G.; Jones, J.W.; Wilkens, P.W.; Porter, C.H.; Batchelor, W.D.; Hunt, L.A.; Boote, K.J.; Singh, U.; Uryasev, O.; Bowen, W.T.; et al. Decision Support System for Agrotechnology Transfer Version 4.0; University of Hawaii: Honolulu, HI, USA, 2004.

30. Ahuja, L.R.; Johnsen, K.E.; Rojas, K.W. Water and chemical transport in soil matrix and macropores. In Root Zone Wate Quality Model Modeling Management Effects on Water Quality and Crop Production; Ahuja, L.R., Rojas, K.W., Hanson, J.D., Shafer, M.J., Ma, L., Eds.; Water Resources Publications, LLC: Highlands Ranch, CO, USA, 2000; pp. 13-50.

31. Ma, L.; Nielsen, D.C.; Ahuja, L.R.; Malone, R.W.; Saseendran, S.A.; Rojas, K.W.; Hanson, J.D.; Benjamin, J.G. Evaluation of Rzwqm under varying irrigation levels in eastern Colorado. Trans. ASAE 2003, 46, 39-49.

32. Yu, Q.; Saseendran, S.A.; Ma, L.; Flerchinger, G.N.; Green, T.R.; Ahuja, L.R. Modeling a wheat-maize double cropping system in China using two plant growth modules in RZWQM. Agric. Syst. 2006, 89, 457-477. [CrossRef]

33. Beck, H.E.; Zimmermann, N.E.; McVicar, T.R.; Vergopolan, N.; Berg, A.; Wood, E.F. Present and future Köppen-Geiger climate classification maps at 1-km resolution. Sci. Data 2018, 5, 180214. [CrossRef] [PubMed] 
34. Sun, H.; Shen, Y.; Yu, Q.; Flerchinger, G.N.; Zhang, Y.; Liu, C.; Zhang, X. Effect of precipitation change on water balance and WUE of the winter wheat-summer maize rotation in the North China Plain. Agric. Water Manag. 2010, 97, 1139-1145. [CrossRef]

35. Zhang, X.; Chen, S.; Liu, M.; Pei, D.; Sun, H. Improved water use efficiency associated with cultivars and agronomic management in the North China Plain. Agron. J. 2005, 97, 783-790. [CrossRef]

36. Prescott, J.A. Evaporation from a water surface in relation to solar radiation. Trans. R. Soc. Aust. 1940, 46, 114-118.

37. Hansen, J.; Gale, F. China in the Next Decade: Rising Meat Demand and Growing Imports of Feed. 2014. Available online: http://www.ers.usda.gov/amber-waves/2014-april/china-in-the-next-decade-rising-meatdemand-and-growing-importsof-feed.aspx\#.VZloZ_lViko (accessed on 29 April 2014).

38. Zhang, Q.; Ren, L. Applying Application of Root Zone Water Quality Model to simulate water and nitrogen use efficiency of winter wheat-summer maize double cropping system I. Model Calibration and sensitivity analysis. J. Hydraul. Eng. 2012, 43, 84-90. (In Chinese)

39. Jaynes, D.B.; Miller, J.G. Evaluation of the Root Zone Water Quality Modelusing data from the Iowa MSEA. Agron. J. 1999, 91, 192-200. [CrossRef]

40. Lin, D.; Jin, M.; Liang, X.; Zhan, H. Estimating groundwater recharge beneath irrigated farmland using environmental tracers fluoride, chloride and sulfate. Hydrogeol. J. 2013, 21, 1469-1480. [CrossRef]

41. Yang, X.; Chen, Y.; Pacenka, S.; Gao, W.; Zhang, M.; Sui, P.; Steenhuis, T.S. Recharge and groundwater use in the North China Plain for six irrigated crops for an eleven year period. PLoS ONE 2015, 10, e0115269. [CrossRef]

42. Huang, P.; Zhang, J.; Zhu, A.; Li, X.; Ma, D.; Xin, X.; Zhang, C.; Wu, S.; Garland, G.; Pereira, E.I.P. Nitrate accumulation and leaching potential reduced by coupled water and nitrogen management in the Huang-Huai-Hai Plain. Sci. Total Environ. 2018, 610-611, 1020-1028. [CrossRef]

43. Li, Z.; Wen, X.; Hu, C.; Li, X.; Li, S.; Zhang, X. Regional simulation of nitrate leaching potential from winter wheat-summer maize rotation croplands on the North China Plain using the NLEAP-GIS model. Agric. Ecosyst. Environ. 2020, 294, 106861. [CrossRef]

44. Turkeltaub, T.; Jia, X.; Zhu, Y.; Shao, M.-A.; Binley, A. Recharge and nitrate transport through the deep vadose zone of the Loess Plateau: A regional-scale model investigation. Water Resour. Res. 2018, 54, 4332-4346. [CrossRef]

45. Chen, J.Y.; Tang, C.Y.; Shen, Y.J.; Sakura, Y.; Kondoh, A.; Shimada, J. Use of water balance calculation and tritium to examine the dropdown of groundwater table in the piedmont of the North China Plain (NCP). Environ. Geol. 2003, 44, 564-571. [CrossRef]

46. Cao, G.; Zheng, C.; Scanlon, B.R.; Liu, J.; Li, W. Use of flow modeling to assess sustainability of groundwater resources in the North China Plain. Water Resour. Res. 2013, 49, 159-175. [CrossRef]

47. Pei, H.; Min, L.; Qi, Y.; Liu, X.; Jia, Y.; Shen, Y.; Liu, C. Impacts of varied irrigation on field water budegts and crop yields in the North China Plain: Rainfed vs. irrigated double cropping system. Agric. Water Manag. 2017, 190, 42-54. [CrossRef]

48. Sun, S.K.; Yin, Y.L.; Wu, P.T.; Wang, Y.B.; Luan, X.B.; Li, C. Geographical evolution of agricultural production in China and its effects on water stress, economy, and the environment: The virtual water perspective. Water Resour. Res. 2019, 55, 4014-4029. [CrossRef]

49. Liu, S.; Mo, X.; Lin, Z.; Xu, Y.; Ji, J.; Wen, G.; Richey, J. Crop yield responses to climate change in the Huang-Huai-Hai Plain of China. Agric. Water Manag. 2010, 97, 1195-1209. [CrossRef]

50. Liu, Q.; Yan, C.; Ju, H.; Garré, S. Impact of climate change on potential evapotranspiration under a historical and future climate scenario in the Huang-Huai-Hai Plain, China. Theor. Appl. Climatol. 2017, 132, 387-401. [CrossRef]

51. Cui, J.; Yan, P.; Wang, X.; Yang, J.; Li, Z.; Yang, X.; Sui, P.; Chen, Y. Integrated assessment of economic and environmental consequences of shifting cropping system from wheat-maize to monocropped maize in the North China Plain. J. Clean. Prod. 2018, 193, 524-532. [CrossRef]

52. Fang, Q.; Zhang, X.; Chen, S.; Shao, L.; Sun, H. Selecting traits to increase winter wheat yield under climate change in the North China Plain. Field Crop. Res. 2017, 207, 30-41. [CrossRef]

53. Wang, J.; Wang, E.; Yang, X.; Zhang, F.; Yin, H. Increased yield potential of wheat-maize cropping system in the North China Plain by climate change adaptation. Clim. Chang. 2012, 113, 825-840. [CrossRef] 
54. Xiao, D.; Tao, F. Contributions of cultivars, management and climate change to winter wheat yield in the North China Plain in the past three decades. Eur. J. Agron. 2014, 52, 112-122. [CrossRef]

55. Luo, J.; Shen, Y.; Qi, Y.; Zhang, Y.; Xiao, D. Evaluating water conservation effects due to cropping system optimization on the Beijing-Tianjin-Hebei plain, China. Agric. Syst. 2018, 159, 32-41. [CrossRef]

56. Hanson, J.D.; Rojas, K.W.; Shaffer, M.J. Calibrating the root zone water quality model. Agron. J. 1999, 91, 171-177. [CrossRef]

57. Cai, B.; Zhang, W.; Hubacek, K.; Feng, K.; Li, Z.; Liu, Y.; Liu, Y. Drivers of virtual water flows on regional water scarcity in China. J. Clean. Prod. 2019, 207, 1112-1122. [CrossRef]

58. Ren, D.; Yang, Y.; Yang, Y.; Richards, K.; Zhou, X. Land-Water-Food Nexus and indications of crop adjustment for water shortage solution. Sci. Total Environ. 2018, 626, 11-21. [CrossRef] [PubMed]

59. Wang, Y.; Zhang, L.; Zhou, N.; Xu, L.; Zhu, J.; Tao, H.; Huang, S.; Wang, P. Late harvest and foliar fungicide acted together to minimize climate change effects on summer maize yield in the North China Plain during 1954-2015. Agric. Ecosyst. Environ. 2018, 265, 535-543. [CrossRef]

60. Yan, P.; Tao, Z.; Chen, Y.; Zhang, X.; Sui, P. Spring maize kernel number and assimilate supply responses to high-temperature stress under field conditions. Agron. J. 2017, 109, 1433-1442. [CrossRef]

61. He, Y.; Shi, Y.; Liang, H.; Hu, K.; Hou, L. Soil water and nitrogen fluxes in response to climate change in a wheat-maize double cropping system. Agronomy 2020, 10, 786-799. [CrossRef]

Publisher's Note: MDPI stays neutral with regard to jurisdictional claims in published maps and institutional affiliations. 